\title{
Impact of South African fortification legislation on product formulation for low-income households
}

\author{
Sara S. Duvenage ${ }^{\mathrm{a},}$ and Hettie C. Schönfeldt ${ }^{\mathrm{b}}$ \\ ${ }^{\mathrm{a}}$ Department of Hospitality and Tourism, Private Bag X021, Vaal University of \\ Technology, P.O. Bag X021, Vanderbijlpark, Gauteng 1900, South Africa \\ ${ }^{\mathrm{b}}$ Department of Consumer Science, University of Pretoria, South Africa
}

\begin{abstract}
Newly introduced legislation for the fortification of maize meal and bread flour in South Africa enhanced nutritive intakes for selected nutrients and enabled the formulation of an affordable, dry, plant-based premixed food product for low-income households. Firstly, the nutritive intakes and relatedness to prevalent nutrient deficiencies in South Africa were calculated to portray the impact of the implemented food fortification legislation [Republic of South Africa (RSA), 2003. Department of Health. Government notice. No. R2003. Regulations relating to the fortification of certain foodstuffs. Section 15(1) of the Foodstuffs, Cosmetics and Disinfectants Act, No. 54 of 1972. Retrieved February 25, 2005, http://0-www.doh.gov.za.innopac.up.ac.za:80/search/default.asp]. Despite fortification, nutritive intakes were still significantly less than recommended. Linear programming was then applied to plot the estimated average requirements (EAR) for females (19-50 years) against nutritive content and cost of $100 \mathrm{~g}$ cooked product of each of the constituent ingredients of the premix product. Programming constraints were manipulated to identify the most viable ratio of possible ingredients to satisfy the indicated nutritive requirements and affordability. Due to fortification, vitamin A was eliminated as major formulation constraint, enabling satisfaction for vitamin A, zinc, iron and folate. Constraints for pyridoxine, riboflavin and thiamine were alleviated, facilitating product formulation. The provisioning for energy $(-5 \%)$ and potassium $(-7 \%)$
\end{abstract}


were indicated as limitations and relaxed to derive a reasonable answer. However, nutrients naturally restricted in cereal grains and legumes could not be provided for. The approach as developed could be applied by industry and others to enhance affordable and sustained nutrient intake to survival households.

\section{Article Outline}

1. Introduction

2. Population at risk

3. Methods

3.1. Phase 1: Nutritive intake of the population at risk

3.2. Phase 2: Food product formulation

4. Results and discussion

4.1. Phase 1: Nutritive intake of the population at risk

4.1.1. Current staple food intakes

4.1.2. Impact of bread flour and maize meal fortification on adequacy of nutritive intakes of female caregivers

4.2. Phase 2: Food product formulation

4.2.1. Food product constraints

4.2.2. Optimisation of food product formulation

5. Conclusions

6. Recommendations

Acknowledgements

References

\section{Introduction}

Hunger and malnutrition are unacceptable in a world that has both the knowledge and the resources to end this human catastrophe (FAO, 1992).

In 2004, the global situation indicated 815 million people in developing countries as undernourished (SOFI, 2004). Of special concern is the situation in Central, East and 
Southern Africa where $44 \%$ of the population were indicated (FIVIMS, 2004). The depth of hunger was indicated as the greatest for Sub-Saharan Africa $(<1260 \mathrm{~kJ} /$ day) (FAO, 2002). Since the change in the political dispensation in South Africa in 1994 enormous instant residential areas formed, accumulating most of the one million people urbanised every year into geographically vulnerable pockets of high population density and unemployment, and therefore urban poor (Van Wyk et al., 2002). Two and a half million people live in shacks in the Johannesburg area alone (Collins, 2001). Consequently, the population sector not proficient in the self-production of food is increasing rapidly, and factors such as compromised food availability, utilisation or consumption by the household, as well as distribution within the household were impacting on food security (Pelletier et al., 2001; Mater and Gordon, 1996; Maxwell and Frankengerger, 1992). Inadequate access to food (75\%), and resultant hunger (50\%), culminated in only one out of four South African households being food-secure (Schmidt et al., 2002).

As income is a significant determinant of nutritional status and food availability in both rural and urban households (Cade et al., 1999), it follows that people with low incomes are least likely to eat healthy diets (Ruel et al., 2001). Very poor families consume only staple foods and other foods that are grown (Garrow et al., 2000). The judicious combination of plant foods can improve nutritive intake, creating the option for rehabilitation through diversification.

The South African Food Consumption Studies (SAFCS) undertaken amongst different population groups (1983-2000) (Nel and Steyn, 2002) to estimate the usual food consumption in both urban and rural areas, indicated maize, samp/mealie rice (grits), white rice, peanut butter and dry beans as the main contributors to staple cereal and legume intakes for people 10 years and older. The staples most consumed were indicated as maize and wheat products, with average intakes of $423 \mathrm{~g} /$ day (by $86 \%$ of the population), and $103 \mathrm{~g} /$ day (by $62 \%$ of the population) respectively.

Accordingly, protein quality becomes crucial with marginal intakes of protein-rich foods. Through the strategy of mutual supplementation of plant protein, complementary proteins are yielded that contain all the essential amino acids in quantities sufficient to support health, in one meal. When consumed separately, isoleucine and lysine are indicated as the limiting essential amino acids in legumes, and methionine and tryptophane in grains. 
When used in combination, the limitation in essential amino acids is alleviated. The judicious utilisation of the nutritive value of cereal grains and legumes in combination may impact on the development of future products.

Government Notice (Section 15(1) of the Foodstuffs, Cosmetics and Disinfectants Act, Act No 54 of 1972), required all maize meal and bread flour milled in South Africa to contain specified amounts of vitamin A palmitate, thiamin mononitrate, riboflavin, nicotinamide/niacinamide, pyridoxine $\mathrm{HCl}$, folic acid, electrolytic iron, and zinc oxide (RSA, 2003).

The ingredients being fortified include super, special, sifted and unsifted maize meal and wheat flour with an ash content of more than $0.6 \%$ on a moisture-free basis. Within the population at risk, special maize meal is utilised by $42 \%$, and sifted maize meal by $52 \%$ of the community as staple food intake (Amuli, 2005). The adjustment in the nutritive content of sifted maize meal and brown bread, as the staples consumed by most of the target population, are reported in Table 1.

Table 1.

Micronutrient composition of fortified food stuffs: staples mostly consumed by the target population (RSA, 2003)

\begin{tabular}{|l|l|l|l|l|l|}
\hline Micronutrients & Fortification & Natural & Total & Tolerance (\%) & Netto \\
\hline Composition of sifted maize meal (1 kg flour) & \multicolumn{5}{l|}{} \\
\hline Vitamin A ( $\mu \mathrm{g}$ RE) & 2085 & 0 & 2085 & \pm 10 & 1877 \\
\hline Thiamine (mg) & 2.1875 & 3.1 & 5.2875 & \pm 10 & 4.7588 \\
\hline Riboflavin (mg) & 1.6875 & 0.5 & 2.1875 & \pm 10 & 1.9688 \\
\hline Niacin (mg) & 25 & 13.5 & 38.5 & \pm 10 & 34.65 \\
\hline Pyridoxine (mg) & 3.125 & 2.2 & 5.325 & \pm 10 & 4.7925 \\
\hline Folic acid (mg) & 2 & 0.14 & 2.14 & \pm 10 & 1.926 \\
\hline Iron (mg) & 35 & 14.2 & 49.2 & \pm 10 & 44.28 \\
\hline Zinc (mg) & 15 & 14.55 & 29.55 & \pm 10 & 26.595 \\
\hline Composition per 1 kg brown bread $( \pm 667$ g flour) & & \\
\hline
\end{tabular}




\begin{tabular}{|c|c|c|c|c|c|}
\hline Micronutrients & Fortification & Natural & Total & Tolerance (\%) & Netto \\
\hline Vitamin A ( $\mu \mathrm{g} R E)$ & 734 & 0 & 734 & \pm 5 & 700 \\
\hline Thiamine (mg) & 1.0272 & 1.8 & 2.8272 & \pm 10 & 2.5445 \\
\hline Riboflavin (mg) & 0.9391 & 0.6 & 1.5391 & \pm 10 & 1.3852 \\
\hline Niacin (mg) & 13.2066 & 33 & 46.2066 & \pm 10 & 41.5859 \\
\hline Pyridoxine (mg) & 1.4674 & 1.5 & 2.9674 & \pm 10 & 2.6707 \\
\hline Folic acid (mg) & 0.587 & 0.23 & 0.8196 & \pm 10 & 0.7353 \\
\hline Iron (mg) & 20.5436 & 18 & 38.5436 & \pm 10 & 34.6892 \\
\hline Zinc (mg) & 8.8044 & 13.5 & 22.3044 & \pm 10 & 20.074 \\
\hline
\end{tabular}

The purpose of this article is to determine the influence of fortification of maize meal and bread flour, as the staple foods most consumed by the target population, on the formulation of a cereal grain and legume-based dry premixed food product optimised for nutritive content and affordability for very low-income households. The identification of the food product formulation constraints, apart from meeting the dietary inadequacy of the population at risk, will not be discussed in this article. The methods, results and discussion, as well as the conclusions, will however be presented.

\section{Population at risk}

An informal settlement was identified for inclusion in the baseline study due to the size of the settlement (1260 households) and geographical positioning (distance from town) (Oldewage-Theron et al., 2005b). Poverty, malnutrition and the household's chronic food insecurity were indicated as the major problems experienced, and these were mainly attributed to inadequate food consumption. The household female caregivers (368 respondents between 19 and 50 years) were identified as experiencing the worst level of food insecurity of all household members and were therefore used as reference in this study to ensure compliance to nutritive needs. 


\section{Methods}

A two-phased approach was followed to link the existing nutritive shortfalls in the community at risk, to the impact of fortification legislation on nutritive intake and food product formulation for supportive nutritive content and affordability.

\subsection{Phase 1: Nutritive intake of the population at risk}

The staple food consumption for female caregivers in the informal settlement was calculated from a baseline study conducted in the same community (Oldewage-Theron et al., 2005b), using the Foodfinder Dietary Analysis 3 program from the Medical Research Council. The data for nutritive intake were screened to include only the referred section of the population. To create a clearer understanding of the situation, a comparison was drawn between the average staple food consumption of female caregivers in the population at risk and the average South African staple food consumption (see Table 2). Maize meal porridge and brown bread were identifiable as the staple foods most frequently consumed by most of the female caregivers.

Table 2.

Cereal grains, legumes and bread staples commonly consumed by adults

\begin{tabular}{|l|l|l|l|l|l|}
\hline & \multicolumn{3}{|l|}{ South Africa $^{\text {I }}$} & \multicolumn{3}{l|}{ Informal settlement $^{\mathbf{b}}$ (n=368) } \\
\hline & g/person/day & \multicolumn{2}{l|}{$\begin{array}{l}\text { \% of target population } \\
\text { consuming the product (\%) }\end{array}$} & g/person/day \\
\hline $\begin{array}{l}\text { Cooked maize } \\
\text { porridge }\end{array}$ & 848 & $<3$ & $<3$ & $93^{\text {d }}$ & $\begin{array}{l}\text { Maize meal } \\
\text { porridge 460 }\end{array}$ \\
\hline $\begin{array}{l}\text { Cooked } \\
\text { samp/mealie rice }\end{array}$ & 407 & $<3$ & $<3$ & 1 & 140 \\
\hline Boiled white rice & 163 & $<3$ & $<3$ & 3 & 179 \\
\hline $\begin{array}{l}\text { Dry beans, } \\
\text { cooked }\end{array}$ & 255 & $<3$ & $<3$ & 2 & \begin{tabular}{l} 
Dried sugar beans: \\
\hline
\end{tabular} \\
\hline White bread & 161 & $<3$ & $<3$ & 8 & 74 \\
\hline
\end{tabular}




\begin{tabular}{|c|c|c|c|c|c|}
\hline \multirow[t]{2}{*}{ Items } & \multicolumn{2}{|l|}{ South Africa ${ }^{a}$} & \multicolumn{3}{|c|}{ Informal settlement ${ }^{b}(n=368)$} \\
\hline & g/person/day ${ }^{c}$ & \multicolumn{3}{|c|}{$\begin{array}{l}\% \text { of target population } \\
\text { consuming the product (\%) }\end{array}$} & g/person/day ${ }^{c}$ \\
\hline Brown bread & 165 & $<3$ & $<3$ & 72 & 18 \\
\hline
\end{tabular}

${ }^{\mathrm{a}}$ Nel and Steyn, 2002.

${ }^{\mathrm{b}}$ Oldewage-Theron et al., $2005 \mathrm{~b}$.

${ }^{c}$ Average g/person/day of those consuming the item.

$\mathrm{d} \%$ of target population that consumed the product.

Adjustments were then calculated to portray the impact of the South African fortification legislation of all maize meal and bread flour (RSA, 2003) on the habitual nutritive intake of the population at risk (see Table 3). Calculations to indicate the adjusted consumption were based on standardised recipes for stiff and soft maize meal "pap" (porridge) which were sourced from the food composition tables of the Medical Research Council (MRC) of South Africa (MRC, 2003). The recipes for the different breads were obtained from the legislation document (RSA, 2003). The fortification standards as specified for super, special, sifted and un-sifted maize meal and bread flour, as related to vitamin A, folate, thiamine, riboflavin, nicotinamide, pyridoxine, iron, and zinc (RSA, 2003), were applied and calculated according the amounts consumed for each of the staple foods affected by legislation. Adjustments for the percentage of true nutrient retention to report absorption by the body and cooking losses (RSA, 2003) were included in the regulations and were not calculated separately. 
Table 3.

Significance of nutritive intakes of female caregivers before and after fortification as compared to the recommended daily allowance

\begin{tabular}{|c|c|c|c|c|c|c|}
\hline \multirow[t]{2}{*}{ Nutrient } & \multirow[t]{2}{*}{ Unit } & \multirow[t]{2}{*}{ RDA/AI } & \multicolumn{2}{|c|}{$\begin{array}{l}\text { Informal } \\
\text { settlement }^{\mathrm{a}}\end{array}$} & \multicolumn{2}{|c|}{$\begin{array}{l}\text { Significance of } \\
\text { intake }{ }^{l k, ~ l k ~ a n d ~ l k ~}\end{array}$} \\
\hline & & & $\begin{array}{l}\text { Mean } \\
\text { intake }^{e}\end{array}$ & $\operatorname{SEM}^{\mathrm{f}}$ & $\begin{array}{l}\text { Prior to } \\
\text { fortification }\end{array}$ & $\begin{array}{l}\text { After } \\
\text { fortification }^{g}\end{array}$ \\
\hline Copper & $\mathrm{mg}$ & 9 & 0.36 & 0.02 & -432.00 & \\
\hline Calcium & $\mathrm{mg}$ & 1000 & 114.19 & 8.98 & -98.64 & \\
\hline Folate & $\mu \mathrm{g}$ & 400 & 60.86 & 4.631 & -73.23 & -73.12 \\
\hline Iron & $\mathrm{mg}$ & 18 & 3.36 & 0.253 & -57.87 & -32.09 \\
\hline Selenium & $\mu \mathrm{g}$ & 55 & 9.53 & 0.86 & -52.87 & \\
\hline $\begin{array}{l}\text { Total dietary } \\
\text { fibre }\end{array}$ & $\mathrm{g}$ & 25 & 7.07 & 0.34 & -52.74 & \\
\hline Vit C & $\mathrm{mg}$ & 75 & 12.44 & 1.3496 & -46.35 & \\
\hline Zinc & $\mathrm{mg}$ & 8 & 2.74 & 0.135 & -38.96 & -17.78 \\
\hline Biotin & $\mu \mathrm{g}$ & 30 & 9.93 & 0.529 & -37.94 & \\
\hline Vit $B_{6}$ Pyridoxine & $\mathrm{mg}$ & 1.3 & 0.29 & 0.0268 & -37.69 & -17.54 \\
\hline Potassium & $\mathrm{mg}$ & 2000 & 690.27 & 34.83 & -37.60 & \\
\hline Energy & $\mathrm{kJ}$ & 9247 & 3631.16 & 154.97 & -36.24 & \\
\hline Magnesium & $\mathrm{mg}$ & 320 & 129.61 & 5.32 & -35.79 & \\
\hline Vit D & $\mu \mathrm{g}$ & 5 & 1.36 & 0.1059 & -34.37 & \\
\hline Pantothenate & $\mathrm{mg}$ & 5 & 1.58 & 0.116 & -29.48 & \\
\hline Riboflavin & $\mathrm{mg}$ & 1.1 & 0.31 & 0.0275 & -28.73 & -17.45 \\
\hline
\end{tabular}




\begin{tabular}{|c|c|c|c|c|c|c|}
\hline \multirow[t]{2}{*}{ Nutrient } & \multirow[t]{2}{*}{ Unit } & \multirow[t]{2}{*}{ RDA/AI } & \multicolumn{2}{|c|}{$\begin{array}{l}\text { Informal } \\
\text { settlement }^{\mathrm{a}}\end{array}$} & \multicolumn{2}{|c|}{$\begin{array}{l}\text { Significance of } \\
\text { intake } \mathrm{e}^{\mathrm{k}, \text { lk and } \mathrm{lk}}\end{array}$} \\
\hline & & & $\begin{array}{l}\text { Mean } \\
\text { intake }\end{array}$ & SEM $^{f}$ & $\begin{array}{l}\text { Prior to } \\
\text { fortification }\end{array}$ & $\begin{array}{l}\text { After } \\
\text { fortification }^{\mathrm{g}}\end{array}$ \\
\hline Vit A RE & $\mu \mathrm{g}$ & 700 & 175.49 & 18.484 & -28.38 & -10.70 \\
\hline Niacin & $\mathrm{mg}$ & 14 & 4.3 & 0.355 & -27.32 & -14.34 \\
\hline Thiamin & $\mathrm{mg}$ & 1.1 & 0.54 & 0.027 & -20.74 & -6.30 \\
\hline Lysine $^{h}$ & $\mathrm{~g}$ & 2.668 & 1.35 & 0.0666 & -19.79 & \\
\hline $\begin{array}{l}\text { Phenylalanine \& } \\
\text { tyrosine }\end{array}$ & $\mathrm{g}$ & 2.898 & 1.46 & 0.073 & -19.70 & \\
\hline Total protein & g & 46 & 23.2 & 1.18 & -19.32 & \\
\hline Phosphorus & $\mathrm{mg}$ & 700 & 373.43 & 17.18 & -19.01 & \\
\hline Tryptophan $^{\mathrm{h}}$ & $\mathrm{g}$ & 0.506 & 0.26 & 0.0135 & -18.22 & \\
\hline Threonine $^{\mathrm{h}}$ & g & 1.564 & 0.79 & 0.0445 & -17.39 & \\
\hline $\begin{array}{l}\text { Methionine \& } \\
\text { cystine }^{\mathrm{h}}\end{array}$ & $\mathrm{g}$ & 1.15 & 0.58 & 0.0369 & -15.45 & \\
\hline Leucine $^{\mathrm{h}}$ & g & 3.036 & 1.53 & 0.098 & -15.37 & \\
\hline Vit E & $\mathrm{mg}$ & 15 & 6.92 & 0.5378 & -15.02 & \\
\hline Valine $^{\mathrm{h}}$ & $\mathrm{g}$ & 1.61 & 0.81 & 0.054 & -14.81 & \\
\hline Isoleucine $^{\mathrm{h}}$ & g & 1.288 & 0.65 & 0.0458 & -13.93 & \\
\hline Histidine $^{\mathrm{h}}$ & g & 0.874 & 0.44 & 0.0312 & -13.91 & \\
\hline Vit $B_{12}$ & $\mu \mathrm{g}$ & 2.4 & 1.18 & 0.1098 & -11.11 & \\
\hline $\begin{array}{l}\text { Polyunsaturated } \\
\text { FA }\end{array}$ & $\mathrm{g}$ & 17 & 9.47 & 0.69 & -10.91 & \\
\hline Chromium & $\mu \mathrm{g}$ & 25 & 12.9 & 1.18 & -10.25 & \\
\hline Total fat & $\mathrm{g}$ & 30 & 25.04 & 1.63 & -3.04 & \\
\hline Carbohydrate, & g & 130 & 128.7 & 4.75 & -0.27 & \\
\hline
\end{tabular}




\begin{tabular}{|l|l|l|l|l|l|l|}
\hline Nutrient & Unit & RDA/AI & $\begin{array}{l}\text { Informal } \\
\text { settlement }\end{array}$ & \multicolumn{2}{|l|}{$\begin{array}{l}\text { Significance of } \\
\text { intakek, lk and lk }\end{array}$} \\
\hline & & & $\begin{array}{l}\text { Mean } \\
\text { intake }^{\text {e }}\end{array}$ & SEM $^{\mathbf{f}}$ & $\begin{array}{l}\text { Prior to } \\
\text { fortification }\end{array}$ & $\begin{array}{l}\text { After } \\
\text { fortification }\end{array}$ \\
\hline available & & & & & & \\
\hline Vit K & $\mu \mathrm{g}$ & 90 & 91.72 & 9.381 & 0.18 & \\
\hline Manganese & $\mathrm{mg}$ & 1.8 & 0.89 & 0.047 & 19.36 & \\
\hline
\end{tabular}

a (Oldewage-Theron et al., 2005a) and (Oldewage-Theron et al., 2005b).

${ }^{\mathrm{b}}$ Where RDAs were not available, AI (Adequate intakes) was supplied for calculation (Gericke, 2003; NICUS, 2003).

${ }^{c}$ Overall $P<0.01$. Overall $1 \%$ probability of declaring a nutrient lower if it is not.

${ }^{\mathrm{d}} z$-value calculated to standardise the variables ( $z=R D A-$ mean intake/SEM). Any item smaller than 0,34 indicates a significant difference.

${ }^{\mathrm{e}}$ Foodfinder 3 Export Analysis (total intake per day).

${ }^{\mathrm{f}}$ Standard error of mean.

${ }^{\mathrm{g}}$ Contribution made by fortification added to intake prior to fortification. Assumption made that the amount added not subjected to an additional sampling error.

${ }^{\mathrm{h}}$ Indispensable amino acids calculated according to the FAO/WHO PDCAAS (Protein Digestibility Corrected Amino Acid Score) method (Milt-Ward et al., 2004; NICUS, 2003).

Nutrients indicated for intakes less than $67 \%$ of the RDAs for South African children as a whole (Labadarios et al., 2001).

The reporting of nutritive intakes included certain adjustments. The dietary folate equivalent ratio $(1 \mathrm{DFE}=1 \mu \mathrm{g}$ food folate $=0.6 \mu \mathrm{g}$ folic acid from fortified food or supplement consumed with food) was applied to adjust folic acid content (fortified intake) to folate content to report the influence of fortification (Earl and Borra, 2000). For correlation purposes, the content of the essential amino acids was calculated according to the FAO/WHO Protein Digestibility Corrected Amino Acid Score method (PDCAAS) for consumption in the population at risk (Milt-Ward et al., 2004). 
Results were then reflected against the recommended daily allowances (RDA/AI) for females 19-30 and 31-50 years old. Where the recommended allowances differed, the higher recommendation was incorporated (DRIT, 2007; NICUS, 2003; Labadarios et al., 2001). The aim was to indicate the significance of the nutritive intakes of the female caregivers before and after fortification. The correlation with the prevailing nutritional deficiencies in South Africa (Labadarios et al., 2001) were also indicated to highlight the compromised nutritive intakes to receive special attention in food product formulation.

\subsection{Phase 2: Food product formulation}

The constraints pertaining to the cultural and social practices guiding food choice, product acceptance and availability in the household (with special attention to the consumption availability to the female caregiver) (Messina et al., 2004), availability of the cereal grains and legumes for purchasing in the area, as well as applicable legislation, were investigated. The findings are not reported as part of this article.

The prerequisites stipulated by the food product manufacturer (confidential) and the inherent nutritive restrictions of cereal grains and legumes were utilised to guide the choice of dry cereal grains and legumes for food product formulation. A choice of nine cereal grains and legumes were indicated for possible inclusion in the dry premixed product.

To facilitate product formulation, data was calculated for each of the ingredients to include in the matrix of a linear programme regarding the aspects described hereafter. The prices for the included ingredients, indicated in cooked quantities, were calculated using yield factors relating to the ratio of the cooked weight against the uncooked weight of the items (Haytowitz and Matthews, 1986):

\section{Yeld $=\frac{\text { weight of legume, cooked }}{\text { weight of lesums, ureooked }}$}

As food items are consumed with the moisture content as is, no standardisation of moisture content was applied in reporting the nutritive content in the matrix (Southgate, 2000). A restriction of $33.3 \%$ was incorporated not to be exceeded by any single constituent ingredient, and a restriction of $25 \%$ was applied to soy due to consumer 
constraints (pilot study on product prototype). Nutritive content and price was expressed as per $100 \mathrm{~g}$ cooked weight for each of the included cereal grains and legumes. Two portions/day, or $640 \mathrm{~g}$ cooked mixture in addition to the existing diet, was indicated as close as possible maximum parameter for formulation (MRC, 2003). Missing food data were derived through calculation, estimates and information from industry (West and Van Staveren, 1997).

As EAR is an indicator of the minimum nutrient levels to promote an intake with a low prevalence of inadequacy, and because an adjustment for assumed bioavailability of the respective nutrient is included (Gericke 2003; NICUS, 2003), this guideline was utilised as the parameter to indicate satisfaction for minimum nutritive content. In order to apply a linear programming approach, formulation constraints were manipulated to optimise the product for best practice to support the habitual nutritive intake of the population at risk and affordability to enhance nutritive supply in food products to survival households.

\section{Results and discussion}

\subsection{Phase 1: Nutritive intake of the population at risk}

\subsubsection{Current staple food intakes}

Table 2 shows the comparison of the average consumption of the various staple foods between the target group and adults in South Africa. Average portion sizes (g) were indicated for cooked products as consumed by at least $3 \%$ of the indicated target populations (Nel and Steyn, 2002).

The results displayed in Table 2 confirmed the choice of maize meal and bread flour as highly suitable vehicles for micronutrient fortification for very low income households, with stiff and soft maize meal and white and brown bread being the only staple products to be consumed by more than $3 \%$ of the population at risk.

Stiff maize porridge was indicated as the major source of energy for $93 \%$ of the population at risk, contributing $2408 \mathrm{~kJ} /$ person/day (571 kcal), representing $66 \%$ of the total energy intake per day. For $48 \%$ of the population at risk, soft porridge contributed $825 \mathrm{~kJ} /$ person/day $(194 \mathrm{kcal})$. Less than $3 \%$ of the study population consumed food from the additional small range of staples. In comparison, $78 \%$ of the adult population of South Africa consumed $848 \mathrm{~g}$ cooked maize porridge/person/day in combination with various 
other staples (Nel and Steyn, 2002). Of concern is the limited intake of maize meal and bread as related to the limited overall energy intake of the population at risk.

\subsubsection{Impact of bread flour and maize meal fortification on adequacy of nutritive intakes of female caregivers}

The significance of the nutritive intakes, before and after fortification of wheat flour and maize meal, is displayed in Table 3 (DRIT, 2007; NICUS, 2003; Labadarios et al., 2001). The emerging picture indicated the compromised nutritive intakes of the female caregivers. A significant difference between all nutritive intakes, prior to and after fortification, and the RDA/AI was indicated for all relevant fortificants. Prior to fortification, all the indicators for compromised intakes correlated with South African findings, indicating calcium, iron, selenium, vit C, zinc, energy, vit D, riboflavin, vit A, niacin, and vit E, as deficiencies of high concern (Labadarios et al., 2001). In the population at risk, additional pronounced deficiencies in copper, folate, total dietary fibre, biotin, vit $\mathrm{B}_{6}$, potassium, pantotenate, thiamin, and phosphorus were indicated, with concern about the intakes of vit $\mathrm{B}_{12}$, polyunsaturated fatty acids and chromium. Sodium, chloride and iodine were not included for comparison purposes, as iodised salt has not been reported as a compromised intake in the baseline study.

As could be expected from a maize-based diet, lysine (-19.79\%) was indicated as the most limited essential amino acid, followed by phenylalanine and tyrosine $(-9.7 \%)$, tryptophan $(-18.22 \%)$, treonine $(-17.39 \%)$, methionine and cystine $(-15.45 \%)$, leucine $(-15.37 \%)$, valine $(-14.81 \%)$, and then isoleucine $(-13.93 \%)$ and histidine $(-13.91 \%)$. Despite the limited intake of cooked maize meal and bread by the female caregivers, the additional amounts of iron $(25.78 \mathrm{mg})$, zinc $(21.18 \mathrm{mg})$, vit $\mathrm{B}_{6}(20.15 \mathrm{mg})$, riboflavin (11.28 mg), vit A (17.68 mcg), niacin (12.98), and thiamin (14.44 mg) supplied through fortification, contributed significantly but did not manage to eliminate deficiencies for this very low-income group (Table 3$)$. Folate intake (0.11 mcg additional), however, was still of high concern. 


\subsection{Phase 2: Food product formulation}

Product formulation parameters indicated an outcome of best practice for supportive nutritive content for identified deficiencies in nutritive intake within constraints after fortification and minimised ingredient cost.

\subsubsection{Food product constraints}

Cereal grains and legumes display natural inherent nutritive restrictions, creating limitations in product formulation. Legumes as a group have a low fat content (1-5\%) and hence a low content of fat-soluble nutrients (Venter and Van Eyssen, 2001). Legumes contain no vitamin $B_{12}$, and very limited vitamin $C$, selenium and biotin, and only some of the legumes contain chromium. Even with the inclusion of soybeans, as an oilseed type of legume containing a relatively high fat content (19.9\%), the need for vitamin $\mathrm{A}, \mathrm{D}$ and $\mathrm{E}$ could not be satisfied within reasonable boundaries of intake and product formulation limitations.

\subsubsection{Optimisation of food product formulation}

It is clear from Table 3 that the nutritive intakes for total fat, polyunsaturated fatty acids, carbohydrate, niacin, vitamin K, leucine and isoleucine were already satisfied (by meeting at least the EAR) through the habitual nutritive intake prior to fortification, with addition of vitamin A and iron after fortification. Through manipulation of programming constraints, it was possible to explore options for best solutions for the remaining compromised dietary intakes at the most affordable price ([Briend et al., 2003] and [Briend et al., 2001]) as can be seen in Table 4.

Table 4.

Summary of findings derived through linear programming

\begin{tabular}{|l|l|l|l|}
\hline Programming constraints & \multicolumn{2}{l|}{ Outcome $^{\mathbf{l k} \text { and } \mathbf{~ l k}}$} \\
\hline Ingredients & Nutrients & Nutrients & $\begin{array}{l}\text { Price of cooked } \\
\text { product }\end{array}$ \\
\hline Option 1 & \multicolumn{2}{|l|}{} \\
\hline $\begin{array}{l}\text { After fortification } \\
\text { 33.33\% restriction, } \\
\text { but 25\% soy }\end{array}$ & $\begin{array}{l}\text { Omitting energy, } \\
\text { potassium }\end{array}$ & $\begin{array}{l}\text { EAR satisfaction for } \\
\text { other nutrients. } \\
\text { Shortfall: 33\% energy, }\end{array}$ & ZAR1.03/469g \\
\hline
\end{tabular}




\begin{tabular}{|c|c|c|c|}
\hline \multicolumn{2}{|c|}{ Programming constraints ${ }^{\mathrm{lk} \text { and lk }}$} & \multicolumn{2}{|l|}{ Outcome $\mathrm{e}^{\mathrm{lk} \text { and lk }}$} \\
\hline Ingredients & Nutrients & Nutrients & $\begin{array}{l}\text { Price of cooked } \\
\text { product }\end{array}$ \\
\hline \multirow[t]{2}{*}{ restriction } & & $34 \%$ potassium & \\
\hline & & & US\$ $0.15 / 469 \mathrm{~g}^{\mathrm{c}}$ \\
\hline \multirow[t]{2}{*}{$\begin{array}{l}\text { Prior to fortification } \\
33.33 \% \text { restriction, } \\
\text { but } 25 \% \text { soy } \\
\text { restriction }\end{array}$} & $\begin{array}{l}\text { Omitting energy, } \\
\text { potassium, vit A (Not } \\
\text { reasonable with } \\
\text { omitting vit A) }\end{array}$ & $\begin{array}{l}\text { EAR satisfaction for } \\
\text { other nutrients. } \\
\text { Shortfall: } 31 \% \text { energy, } \\
29 \% \text { potassium, } 99 \% \\
\text { vit A }\end{array}$ & ZAR1.13/495 g \\
\hline & & & US\$ $0.17 / 495 \mathrm{~g}$ \\
\hline \multicolumn{4}{|l|}{ Option 2} \\
\hline \multirow[t]{2}{*}{$\begin{array}{l}\text { After fortification } \\
33.33 \% \text { restriction, } \\
\text { but } 25 \% \text { soy } \\
\text { restriction }\end{array}$} & $\begin{array}{l}\text { Omitting potassium, } \\
95 \% \text { energy restriction }\end{array}$ & $\begin{array}{l}\text { EAR satisfaction for } \\
\text { other nutrients. } \\
\text { Shortfall: } 5 \% \text { energy, } \\
9 \% \text { potassium }\end{array}$ & ZAR1.51/640 g \\
\hline & & & US\$ $0.15 / 640 \mathrm{~g}$ \\
\hline \multirow[t]{2}{*}{ Prior to fortification } & $\begin{array}{l}\text { Omitting vit A, Not } \\
\text { reasonable }\end{array}$ & $\begin{array}{l}\text { Shortfall: } 31 \% \text { energy, } \\
29 \% \text { potassium }\end{array}$ & ZAR1.13/640 g \\
\hline & & & US\$ $0.17 / 640 \mathrm{~g}$ \\
\hline \multicolumn{4}{|l|}{ Option 3} \\
\hline \multirow[t]{2}{*}{$\begin{array}{l}\text { After fortification } \\
33.33 \% \text { restriction, } \\
\text { but } 20 \% \text { soy } \\
\text { restriction }\end{array}$} & $\begin{array}{l}\text { Omitting potassium, } \\
95 \% \text { energy restriction }\end{array}$ & $\begin{array}{l}\text { EAR satisfaction for } \\
\text { other nutrients. } \\
\text { Shortfall: } 5 \% \text { energy, } \\
13 \% \text { potassium }\end{array}$ & ZAR1.59/640 g \\
\hline & & & US\$ $0.24 / 640 \mathrm{~g}$ \\
\hline \multirow[t]{2}{*}{ Prior to fortification } & $\begin{array}{l}\text { Omitting vit A, Not } \\
\text { reasonable }\end{array}$ & $\begin{array}{l}\text { Shortfall: } 28 \% \text { energy, } \\
25 \% \text { potassium }\end{array}$ & ZAR1.23/640 g \\
\hline & & & US\$ $0.18 / 640 \mathrm{~g}$ \\
\hline \multicolumn{4}{|l|}{ Option 4} \\
\hline $\begin{array}{l}\text { After fortification } \\
33.33 \% \text { restriction }\end{array}$ & $\begin{array}{l}\text { Omitting potassium, } \\
95 \% \text { energy restriction }\end{array}$ & $\begin{array}{l}\text { EAR satisfaction for } \\
\text { other nutrients. } \\
\text { Shortfall: } 5 \% \text { energy, }\end{array}$ & ZAR1.38/640 g \\
\hline
\end{tabular}




\begin{tabular}{|c|c|c|c|}
\hline \multicolumn{2}{|c|}{ Programming constraints ${ }^{\mathrm{lk} \text { and lk }}$} & \multicolumn{2}{|l|}{ Outcome $e^{l k \text { and lk }}$} \\
\hline \multirow[t]{3}{*}{ Ingredients } & Nutrients & Nutrients & $\begin{array}{l}\text { Price of cooked } \\
\text { product }\end{array}$ \\
\hline & & $7 \%$ potassium & \\
\hline & & & US\$ $0.20 / 649 \mathrm{~g}$ \\
\hline \multirow[t]{2}{*}{$\begin{array}{l}\text { Prior to fortification } \\
33.33 \% \text { restriction }\end{array}$} & $\begin{array}{l}\text { Omitting potassium } \\
\text { and vit A, } 95 \% \text { energy } \\
\text { restriction. Not } \\
\text { reasonable with } \\
\text { omitting vit A }\end{array}$ & $\begin{array}{l}\text { EAR satisfaction for } \\
\text { other nutrients. } \\
\text { Shortfall: } 5 \% \text { energy, } \\
7 \% \text { potassium, } 99 \% \\
\text { vit A }\end{array}$ & ZAR1.22/705 g \\
\hline & & & US\$ 0.18/705 g \\
\hline \multicolumn{4}{|l|}{ Option 5} \\
\hline \multirow[t]{2}{*}{$\begin{array}{l}\text { After fortification } \\
33.33 \% \text { restriction }\end{array}$} & $\begin{array}{l}\text { Omitting potassium, } \\
90 \% \text { energy restriction }\end{array}$ & $\begin{array}{l}\text { EAR satisfaction for } \\
\text { other nutrients. } \\
\text { Shortfall: } 10 \% \text { energy, } \\
17 \% \text { potassium }\end{array}$ & ZAR1.23/640 g \\
\hline & & & US\$ $0.18 / 640 \mathrm{~g}$ \\
\hline \multirow[t]{2}{*}{$\begin{array}{l}\text { Prior to fortification } \\
33.33 \% \text { restriction }\end{array}$} & $\begin{array}{l}\text { Omitting potassium } \\
\text { and vit A, } 90 \% \text { energy } \\
\text { restriction. Not } \\
\text { reasonable with } \\
\text { omitting vit A }\end{array}$ & $\begin{array}{l}\text { EAR satisfaction for } \\
\text { other nutrients. } \\
\text { Shortfall: } 10 \% \text { energy, } \\
21 \% \text { potassium, } 99 \% \\
\text { vit A }\end{array}$ & ZAR1.16/669g \\
\hline & & & US\$ $0.17 / 669 \mathrm{~g}$ \\
\hline
\end{tabular}

\footnotetext{
${ }^{a}$ According to constraints for premix formulation stipulated for this project.

${ }^{\mathrm{b}}$ According to linear programming to optimize premix formulation.

${ }^{\mathrm{c}}$ US\$ 1=ZAR 6.76 as applicable on 7 June 2005.
}

Pertaining the impact of the fortification of maize meal and bread flour on product formulation for the very low-income market, it was observed that product formulation was not practically feasible for the nutritive intake prior to fortification, without omitting vitamin A as programming restriction. This, however, was not reasonable (see Table 4). Zinc, iron and folate fortification was not important in optimisation due to the sufficient naturally inherent nutritive content in cereal grains and legumes. Fortification further 
alleviated the depth of nutritive constraints for pyridoxine, riboflavin and thiamin, which facilitated product formulation within the constraints.

Energy and potassium were indicated as the restrictions to be relaxed to derive a reasonable answer for product formulation, allowing scope for satisfying at least the EAR levels for all other indicated nutrients within formulation constraints, including the identified compromised nutritive intakes for South Africa, as regards calcium, zinc, and riboflavin. The EAR levels for iron, vitamin A and niacin were satisfied after fortification, prior to optimisation. As a result of the inherent restrictions of cereal grains and legumes, optimisation of vitamin C, D, E, B 12 , biotin and selenium levels could not be satisfied in this formulation and will be addressed in a different phase of product development.

From the summary of findings (see Table 4), it was clear that the options investigated presumably indicated formulations obtained for lower cost as more energy-restricted; and higher soy restrictions as more expensive to satisfy nutritive needs in product formulation. The difference between options 4 and 5 after fortification indicated that an additional $5 \%$ energy and $10 \%$ potassium could be obtained in product formulation for the price of US\$ 0.02 (ZAR 0.15)/640 g of cooked cereal grain and legume mixture/day. For the purpose of this project option 4 (after fortification) was of special interest. It was further possible to identify various other options, for example the three cheapest feasible combinations.

Based on these findings, the formulation of an uncooked, dry cereal grain and legume premix product could be derived by calculating the ratio of the ingredients and affordability, to best provide in the nutritive shortfalls of the habitual nutritive intake of the target population.

\section{Conclusions}

The need for and value of an approach that integrates the specific efficacious nutritive need/s of the population at risk, food product formulation constraints and aims, were confirmed in this study. However, the nutrient content of the constituent ingredients needs to be known as it forms the basis of the calculation. 
The food consumption of female caregivers living in very low income households (Oldewage-Theron et al., 2005a) consisted mainly of cooked maize meal and a limited quantity of bread as staple foods (see Table 2), compromising the nutritive intake for most nutrients (see Table 3) significantly. The scope of nutrients already recognised as compromised in South Africa (Labadarios et al., 2001), manifested in the study population in an exacerbated manner (Table 3).

Although the government regulations for the fortification of maize meal and wheat flour in South African (DoH, 2003) impacted significantly on the adequacy of the nutritive intake for six of the seven nutrients implicated, the EAR level could not be reached. Folate supply was still of major concern (see Table 3).

The linear programming approach allowed scope for the inclusion of constraints to guide food product formulation within parameters for best practice applicable to the specific project challenges faced, of which portion size, nutritive content, maximum ratio allowed for constituent ingredients and affordability were indicators in this specific scenario. The application of this approach, prior to and after fortification, proved linear programming as a valuable tool to assist in the delivery of a formulation ratio for optimised food product formulation to support the specific nutritive needs of the population at risk in a costsensitive manner within formulation constraints.

Overall, the derived formulation reflected the enabling impact of the fortification legislation to enhance affordable optimised food product formulation to address the nutritive needs of female caregivers in very low-income households.

\section{Recommendations}

This approach, which was developed for best practice, could be applied by industry, organisations assisting in food need alleviation programmes and government initiatives to enhance sustained nutritive intake to populations at risk by making food products as affordable as possible.

Further research to address the specific needs for vitamin $B_{12}, C, D, E$, selenium, biotin and chromium will be conducted in a follow-up stage of this project. Product prototypes will be formulated and tested to guide the most feasible option for consumer product acceptance. Finally, the nutrient content of all derived formulations needs to be 
analytically determined in the process to ensure reliable data.

\section{References}

Amuli, 2005 Amuli, D.J., Purchasing Patterns for Major Plant Staples in Low-Income Households in the Vaal Region. Master's Study in Progress, 2005, Vaal University of Technology, South Africa.

Briend et al., 2001 A. Briend, E. Ferguson and N. Darmon, Local food price analysis by linear programming: a new approach to assess the economic value of fortified food supplements, Food and Nutrition Bulletin 22 (2) (2001), pp. 184-189.

Briend et al., 2003 A. Briend, N. Darmon, E. Ferguson and J.G. Erhard, Linear programming: a mathematical tool for analyzing and optimizing children's diets during the complementary feeding period, Journal of Paediatric Gastroenterology and Nutrition 36 (1) (2003), pp. 12-22.

Cade et al., 1999 J. Cade, H. Upmeier, C. Calvert and D. Greenwood, Cost of a healthy diet, Public Health Nutrition 2 (4) (1999), pp. 505-512.

Collins, 2001 Collins J., 2001. Urbanisation. Retrieved January 17, 2005, http://www.botany.uwc.ac.za/Envfacts/facts/urbanisation.htm.

DRIT., 2007 DRIT. Dietary Reference Intake Tables. Retrieved February 26, 2007, http://0-www.hc-sc.gc.ca.innopac.up.ac.za:80/fnan/nutrition/reference/table/ref_vitam/tbl/e.html. Earl and Borra, 2000 R. Earl and S.T. Borra, Guidelines for dietary planning. In: L.K. Mahan and S. Escott-Stump, Editors, Krause's Food, Nutrition and Diet Therapy (10th ed), Saunders, Philadelphia (2000), pp. 32-352.

Food and Agriculture Organization of the United Nations., 1992 FAO. Food and Agriculture Organization of the United Nations., 1992. World Declaration on Nutrition. International Conference of Nutrition, Rome, Italy. Retrieved June 16, 2005, http://www.healthydocuments.info/nutrition/doc31.html. Food and Agriculture Organization of the United Nations, 2002 FAO. Food and Agriculture Organization of the United Nations, 2002. Progress in reducing hunger has virtually halted. Retrieved February 12, 2005, http://0www.fao.org.innopac.up.ac.za:80/english/newsroom/news/2002/9620-en.html. 
Food Insecurity and Vulnerability Information Mapping System, 2004 FIVIMS. Food Insecurity and Vulnerability Information Mapping System, 2004. What is meant by food insecurity and vulnerability? Retrieved January 24, 2005, http://www.fivims.net/static.jspx?lang=en\%page=overview.

Garrow et al., 2000 J.S. Garrow, W.P.T. James and A. Ralph, Human Nutrition and Dietetics, Churchill Livingstone, London (2000).

Gericke, 2003 G.J. Gericke, Better eating for better health: principles and practices of planning a healthful diet. In: H.C. Schönfeldt, Editor, Fundamentals of Nutrition Security in Rural Development: Graduate Readings Vol. 3, University of Pretoria, Pretoria (2003), pp. 227-253.

Haytowitz and Matthews, 1986 D.B. Haytowitz and R.H. Matthews, Composition of Foods: Legumes and Legume Products. Agriculture Handbook (8-16), US Department of Agriculture. US Government Printing Office, Washington, DC (1986).

Labadarios et al., 2001 D. Labadarios, N. Steyn, E. Mauder, U. Macintyre, R. Swart, G. Gericke, J. Huskisson, A. Dannhauser, H.H. Vorster and A.E. Nesamvuni, National food consumption survey in children aged 1-9 years: South Africa 1999, Medical Update 37 (2001), pp. 1-8.

Mater and Gordon, 1996 A. Mater and A. Gordon, Emerging issues confronting the renewable natural resources sector in Sub-Saharan Africa, Food Policy 21 (2) (1996), pp. 229-241.

Maxwell and Frankengerger, 1992 S. Maxwell and T.R. Frankenberger, Household Food Security: Concepts, Indicators, Measurements: a Technical Review, UNICEF, New York (1992).

Medical Research Council., 2003 Medical Research Council. 2003. Foodfinder Dietary Analysis 3.

Messina et al., 2004 F. Messina, A. Saba, C. Vollono, C. Leclercq and R. Piccinelli, Beliefs and attitudes towards the consumption of sugar-free products in a sample of Italian adolescents, European Journal of Nutrition 58 (2004), pp. 420-428. Milt-Ward et al., 2004 Milt-Ward, D.J., Newsholme, E.A., Pellett, P.L., Uauy, R., 2004. Amino acid scoring in health and disease. Retrieved March 26, 2005, http://0www.edu.innopac.up.ac.za:80/unupress/food2/UID07/uid07e1k.htm. 
Nel and Steyn, 2002 J.H. Nel and M. Steyn, Report on South African Food Consumption Studies Undertaken Amongst Different Population Groups (1983-2000): Average Intakes of Foods Most Commonly Consumed, Directorate: Food Control, Department of Health, Pretoria (2002).

Nutrition Information Centre and University of Stellenbosch., 2003 NICUS. Nutrition Information Centre, University of Stellenbosch., 2003. Dietary Reference Intakes. Retrieved May 30, 2003, http://0-www.sun.ac.za.innopac.up.ac.za:80/nicus. Oldewage-Theron et al., 2005a W.H. Oldewage-Theron, E.G. Dicks, C.E. Napier and R. Rutengwe, Situation analysis of an informal settlement in the Vaal Triangle, Development Southern Africa 22 (1) (2005), pp. 13-26.

Oldewage-Theron et al., 2005b W.H. Oldewage-Theron, E.G. Dicks, C.E. Napier and R. Rutengwe, A community-based integrated nutrition research programme to alleviate poverty: baseline survey, Public Health 119 (2005), pp. 312-320.

Pelletier et al., 2001 D.L. Pelletier, C.M. Olson and E.A. Frongillo, Food insecurity, hunger, and undernutrition. In: B.A. Bowman and R.M. Russell, Editors, Present Knowledge in Nutrition (eighth ed), ILSI, Washington, DC (2001), pp. 701-713. RSA, 2003 RSA, 2003. Republic of South Africa, Department of Health, Government notice. No. R2003. Regulations relating to the fortification of certain foodstuffs. Section 15(1) of the Foodstuffs, Cosmetics and Disinfectants Act, No. 54 of 1972. Retrieved February 25, 2005, http://0-www.doh.gov.za.innopac.up.ac.za:80/search/default.asp. Ruel et al., 2001 M. Ruel, J.L. Garrett, S.S. Morris, D. Maxwell, A. Oshaug, P. Engle, P. Menon, A. Slack and L. Haddad, Urban challenges to food and nutrition security: a review of food security, health and care giving in the cities, International Food Policy Research Institute Discussion Paper Briefs 51 (2001), pp. 1-2.

Schmidt et al., 2002 Schmidt, M., Jurgens, A., Jordan, B., 2002. Dread diseases hit South Africa's starving kids: three-quarters of all South Africans do not have enough food. Sunday Times, 28 July, p. 1.

SOFI, 2004 SOFI, 2004. State of Food Insecurity of the World. Undernourishment around the world. Retrieved January 24, 2005, http://0www.fao.org.innopac.up.ac.za:80/docrep/007/y5650e/y5650e03.htm. 
Southgate, 2000 D.A.T. Southgate, Food composition tables and nutritional databases. In: J.S. Garrow, W.P.T. James and A. Ralph, Editors, Human Nutrition and Dietetics (tenth ed), Churchill Livingstone, Edinburgh (2000), pp. 303-310.

Van Wyk et al., 2002 J. Van Wyk, T.J. Britz and A.S. Myburgh, Arguments supporting kefir marketing to the low-income urban African population in South Africa, Agrekon 41 (1) (2002), pp. 43-61.

Venter and Van Eyssen, 2001 C.S. Venter and E. Van Eyssen, More legumes for better overall health, South African Journal of Clinical Nutrition 14 (3) (2001), pp. S32-S38. West and Van Staveren, 1997 C.E. West and W.A. Van Staveren, Food consumption, nutrient intake, and the use of food composition tables. In: B.M. Margetts and M. Nelson, Editors, Design Concepts in Nutritional Epidemiology (second ed), Oxford University Press, Oxford (1997), pp. 107-122.

This article is based on a presentation delivered at the University of Pretoria during the 6th International Food Data Conference "Food Composition and the Nutrition Dilemma" 14-16 September 2005.

Corresponding author. Tel.: +27 16950 9279; fax: +27 169509788 . 